\title{
PENGARUH PENGGUNAAN METODE STORYTELLING TERHADAP KETERAMPILAN PROSES SAINS SISWA PADA KONSEP GERAK BENDA DAN ENERGI
}

\author{
lis Widiastuti ${ }^{1}$, Sopyan Hendrayana ${ }^{2}$ \\ 1 Universitas Pendidikan Indonesia, ${ }^{2}$ Universitas Pasundan \\ 2sopyanhendrayana@unpas.ac.id
}

\begin{abstract}
This research is based on a problem that was found when making observations at SDN Ujungberung, especially on the science concept. The problem found is the lack of science process skills possessed by students. The observed science process skills include observing, communicating and concluding. The lack of science process skills is caused by the learning process that has not facilitated students to play an active role in learning and the students' low absorption capacity. To solve these problems, researchers used one of the learning methods using the storytelling method. In this study the design used was quasi experiment by comparing two different elementary school samples, one elementary school was used as the experimental class and the other elementary school was used as the control class. The data analysis technique used is quantitative data analysis technique. Based on the posttest data analysis technique, normality test, homogeneity test, and two mean difference test (t-test) were used to determine differences in the ability of science process skills in the two samples. The results of data analysis obtained from the two samples come from populations that are normally distributed with a significance value of 0.00 from the criterion of significance value $<0.05(0.00<0.05)$ which means that there are differences in the ability of science process skills between the two samples. The ability of students' science process skills using storytelling methods is better than those using the lecture method. This can be seen in the data gain research results, for the experimental class of 0.47 with a moderate interpretation, while the control class of 0.14 with a low interpretation. In addition, to determine the ability of science process skills in the experimental class the researchers used rating scales. From the results obtained from the three science process skills achieved, the percentage obtained is $86.1 \%$ with quite good category. Based on the description above, it can be concluded that the storytelling method contributes positively to students' science process skills compared to learning using the lecture method. Therefore, researchers recommend the storytelling method to teachers as an alternative in an effort to improve students' science process skills in science learning.
\end{abstract}

Keywords: storytelling method, science process skills, the concept of object motion and energy

\begin{abstract}
ABSTRAK
Penelitian ini didasarkan pada suatu masalah yang ditemukan saat melakukan observasi di SDN Ujungberung, khususnya pada konsep IPA. Permasalahan yang ditemukan ialah rendahnya keterampilan proses sains yang dimiliki siswa.
\end{abstract}


Keterampilan proses sains yang diamati meliputi keterampilan mengobservasi, mengomunikasikan, dan menyimpulkan. Rendahnya keterampilan proses sains ini disebabkan oleh proses pembelajaran yang belum memfasilitasi siswa untuk berperan aktif dalam pembelajaran serta masih rendahnya daya serap siswa. Untuk menyelesaikan permasalahan tersebut, peneliti menggunakan salah satu metode pembelajaran dengan menggunakan metode storytelling. Dalam penelitian ini desain yang digunakan adalah quasi experiment yaitu dengan membandingkan dua sampel SD yang berbeda, satu SD dijadikan kelas eksperimen dan SD lain dijadikan sebagai kelas kontrol. Teknik analisis data yang digunakan adalah teknik analisis data kuantitatif. Berdasarkan teknik analisis data postest dilakukan uji normalitas, uji homogenitas, dan uji perbedaan dua rerata (uji-t) untuk mengetahui perbedaan kemampuan keterampilan proses sains pada kedua sampel. Hasil analisis data yang diperoleh kedua sampel berasal dari populasi yang berdistribusi normal dengan nilai signifikansi 0,00 dari kriteria nilai signifikansi $<0,05 \quad(0,00$ $<0,05$ ) yang berarti terdapat perbedaan kemampuan keterampilan proses sains antara kedua sampel. Kemampuan keterampilan proses sains siswa yang menggunakan metode storytelling lebih baik dari pada yang menggunakan metode ceramah. Hal ini dapat dilihat pada data gain hasil penelitian, untuk kelas eksperimen sebesar 0,47 dengan interpretasi sedang, sedangkan pada kelas kontrol sebesar 0,14 dengan interpretasi rendah. Selain itu, untuk mengetahui kemampuan keterampilan proses sains pada kelas eksperimen peneliti menggunakan skala rating. Dari hasil yang diperoleh dari tiga keterampilan proses sains yang dicapai, dilihat dari prosentasi yang didapat yaitu sebesar $86,1 \%$ dengan kategori cukup baik. Berdasarkan uraian di atas, dapat disimpulkan bahwa metode storytelling memberikan kontribusi positif terhadap keterampilan proses sains siswa dibandingkan dengan pembelajaran yang menggunakan metode ceramah. Oleh karena itu, peneliti merekomendasikan metode storytelling kepada para guru sebagai salah satu alternatif dalam upaya meningkatkan keterampilan proses sains siswa dalam pembelajaran IPA.

Kata kunci : metode storytelling, keterampilan proses sains, konsep gerak benda dan energi

\section{A. Pendahuluan}

Pembelajaran merupakan suatu hal yang bersifat penting bagi keberlangsungan pendidikan karena pembelajaran dapat membantu siswa dalam memperkaya ilmu. Hal ini berkaitan dengan perkembangan pendidikan. Perkembangan pendidikan sangat penting untuk menunjang efektivitas pembelajaran khususnya dalam meningkatkan mutu pendidikan.

Pembelajaran akan bermakna bagi siswa apabila pembelajaran tersebut ditunjang dengan pendekatan, metode, dan media yang sesuai dengan materi yang akan disampaikan dan sesuai dengan tahap perkembangan siswa. Tentunya penggunaan pendekatan, metode, 
Didaktik : Jurnal IImiah PGSD STKIP Subang, ISSN Cetak : 2477-5673 ISSN Online : 2614-722X Volume VI Nomor 01, Juni 2020

maupun media pada proses pembelajaran perlu disampaikan oleh tenaga pengajar yang profesional. Tenaga pengajar profesional yang dimaksud adalah tenaga pengajar yang mampu menguasai materi, pendekatan, metode maupun media yang akan digunakan. Kebermaknaan dalam suatu pembelajaran sangat penting bagi siswa. Kebermaknaan ini didapat dengan cara mengaitkan informasi yang didapat dari pengetahuan awal siswa yang didapat dari siswa ketika melakukan aktivitas sehari-hari dan mengaitkannya dengan pembelajaran sehingga siswa mendapatkan konsep baru untuk disimpan didaya ingat jangka panjang.

Hal ini sejalan dengan teori David Ausubel (Dahar, 1996: 112) menyatakan 'Belajar bermakna merupakan suatu proses mengaitkan informasi baru pada konsep-konsep relevan yang terdapat dalam struktur kognitif seseorang'.

Selain itu terdapat keterkaitan antara teori yang disampaikan oleh David Ausubel dengan teori yang disampaikan oleh Jean Piaget. Menurut Jean Piaget (Dahar, 1996: 154) bahwa 'tingkat perkembangan siswa sekolah dasar yaitu pada tahap operasional konkret'. Pada tahap operasional konkret ini siswa mulai berpikir ke arah logis dan bukan ke arah perseptual seperti pada tahap pra-operasional. Dalam hal ini, siswa diberikan pengetahuan-pengetahuan berupa pengalaman konkret yang pernah siswa dapatkan dalam lingkungan bermainnya.

Oleh karena itu, diperlukan pembelajaran yang bermakna bagi siwa yang ditunjang dengan pengalaman-pengalaman siswa berdasarkan hal-hal yang konkret maupun benda-benda konkret di sekitarnya. Dengan demikian, pembelajaran akan mudah untuk diingat dan dipahami oleh siswa. Salah satu mata pelajaran yang diselenggarakan dalam pendidikan sekolah dasar (SD) adalah IImu Pengetahuan Alam (IPA), yang bertujuan menanamkan dan mengembangkan pengetahuan, keterampilan sikap, dan nilai ilmiah pada siswa, serta rasa mencintai dan menghargai kebesaran Allah SWT. Hal ini sesuai dengan tujuan dibentuknya mata pelajaran IPA yang terdapat dalam Badan Standar Nasional Pendidikan (BSNP) (2007: 13-14), sebagai berikut.

1. Mengembangkan keterampilan proses untuk menyelidiki alam 
Didaktik : Jurnal IImiah PGSD STKIP Subang, ISSN Cetak : 2477-5673 ISSN Online : 2614-722X Volume VI Nomor 01, Juni 2020

sekitar, memecahkan masalah dan membuat keputusan.

2. Meningkatkan kesadaran untuk berperan serta dalam memelihara, menjaga, dan melestarikan lingkungan alam.

3. Meningkatkan kesadaran untuk menghargai alam dan segala keteraturannya sebagai salah satu ciptan Tuhan.

Data yang didapat dari hasil dari observasi yang telah dilakukan pada salah satu sekolah dasar di Bandung, menunjukkan bahwa dalam kegiatan pembelajaran yaitu dalam mata pelajaran IPA mengenai gerak benda dan energi siswa sering kali kesulitan dalam memahami konsep sehingga tidak dapat memberikan contoh lain mengenai gerak benda dan energi yang telah dipelajari. Pemahaman tersebut dapat dilihat dari cara siswa memberikan pendapat, aktivitas siswa dalam mengikuti proses pembelajaran yang terlihat jenuh, mengantuk dan bosan, serta motivasi siswa pada saat pembelajaran. Terdapat beberapa faktor yang menyebabkan kondisi tersebut dapat terjadi. Faktor- faktor tersebut yaitu cara guru menyampaikan pembelajaran dengan menggunakan pendekatan, metode maupun media yang tidak sesuai dengan materi yang akan disampaikan, guru tidak dapat mengondisikan siswa, pembelajaran yang diberikan tidak terpusat pada siswa, guru hanya memperhatikan beberapa siswa yang terkesan pintar, guru membiarkan siswa lain mengobrol, siswa merasa bosan apabila pembelajaan dilakukan dengan melakukan aktivitas yang sama dalam waktu yang lama misalnya hanya mendengarkan, menulis, dan menjawab pertanyaan dari guru. Selain itu, apabila guru dalam menyampaikan materi terlalu monoton dan tidak sesuai dengan silabus maupun rencana pembelajaran yang sebelumnya telah dirancang, maka besar kemungkinan materi yang disampaikan akan sulit dipahami oleh siswa. Hal tersebut akan membuat siswa bosan dan jenuh dalam mengikuti proses pembelajaran, apalagi saat pembelajaran siswa tidak dilibatkan secara langsung, akibatnya bukan suatu hal yang mustahil apabila siswa kurang antusias, tidak bersemangat, cenderung kurang aktif, dan sering mengobrol.

Dari beberapa faktor yang telah diuraikan, dapat dikatakan bahwa siswa tidak dapat mengikuti 
Didaktik : Jurnal IImiah PGSD STKIP Subang, ISSN Cetak : 2477-5673 ISSN Online : 2614-722X Volume VI Nomor 01, Juni 2020

pembelajaran dengan hanya duduk diam dan mendengarkan guru menjelaskan materi tanpa melakukan aktivitas apapun, karena pada hakekatnya belajar akan lebih bermakna apabila subjek dapat terlibat langsung atau yang lebih dikenal dengan istilah learning by doing. Dengan demikian siswa tidak merasa bosan mengikuti pembelajaran dengan beberapa aktivitas yang dilakukan dalam pembelajaran. Selain itu, pendekatan, metode, dan media sangat menunjang dalam keberhasilan proses belajar mengajar.

Pengetahuan dan pemahaman siswa dapat ditingkatkan melalui keterampilan proses sains yaitu pada saat siswa melakukan observasi melalui percobaan, kemudian mengomunikasikannya bersama siswa lain, dan pada tahap yang terakhir siswa dapat menyimpulkannya. Dengan demikian, guru harus dapat memahami karakter siswa dan menciptakan pembelajaran yang menuntut peran aktif siswa. Uraian tersebut sesuai dengan Yuliariatiningsih dan Irianto (2009: 8D) yang mengemukakan bahwa:

Keterampilan proses sains merupakan keterampilan belajar sepanjang hidup, karena keterampilan ini digunakan dalam kehidupan sehari-hari dan digunakan oleh siswa di sekolah dasar dalam berbagai mata pelajaran. Sehingga dapat membekali siswa untuk memecahkan suatu masalah sehari-hari melalui prosedur keterampilan proses sains.

Permasalahan di atas memberikan andil yang besar terhadap keberhasilan pembelajaran di sekolah, dan guru berperan penting bagi perkembangan siswa. Dengan demikian, suatu metode sangat diperlukan demi keberhasilan proses pembelajaran. Penggunaan metode diterapkan sebagai upaya untuk menciptakan suasana yang kondusif dan menyenangkan.

Berdasarkan latar belakang di atas, penulis memandang bahwa yang menjadi rumusan umum dalam penelitian ini adalah "Apakah penggunaan metode storytelling dalam pembelajaran berpengaruh dalam meningkatkan kemampuan proses sains siswa kelas III SD".

\section{B. Metode Penelitian}

Dalam penelitian ini metode yang digunakan yaitu metode penelitian quasi eksperimen. Alasan pemilihan metode eksperimen pada penelitian karena metode penelitian ini memiliki kesesuaian dengan rumusan masalah yang menyebutkan bagaimana pengaruh metode storytelling terhadap keterampilan proses sains siswa dan adakah perbedaan pengaruh penggunaan metode storytelling pada keterampilan proses sains siswa dibandingkan dengan metode direct teaching. Hal ini dilihat dari bagaimana pada saat siswa diberikan pretest sebelum mendapat perlakuan dan diberikan posttest setelah mendapat perlakuan 
Didaktik : Jurnal IImiah PGSD STKIP Subang, ISSN Cetak : 2477-5673 ISSN Online : 2614-722X

Volume VI Nomor 01, Juni 2020

yaitu pada kelas eksperimen. Begitupun pretest dan posttest diberikan pada kelas kontrol. Hanya

saja pada kelas kontrol tidak mendapat perlakuan yang sama dengan kelas eksperimen.

\section{Hasil Penelitian dan Pembahasan}

Tabel 1

Hasil Uji Perbedaan Dua Rerata Pretest Kelas Eksperimen dan Kelas Kontrol

\begin{tabular}{|c|c|c|c|c|c|c|c|c|c|}
\hline \multicolumn{10}{|c|}{ t-tes for Equality of Means } \\
\hline \multirow[t]{2}{*}{$\begin{array}{l}\text { Independent } \\
\text { Sample Test }\end{array}$} & \multicolumn{2}{|c|}{$\begin{array}{l}\text { Levene's } \\
\text { Test for } \\
\text { Equality } \\
\text { of } \\
\text { Variances }\end{array}$} & & & & & & \multicolumn{2}{|c|}{$\begin{array}{c}95 \% \\
\text { Confidences } \\
\text { Interval of } \\
\text { the } \\
\text { Difference }\end{array}$} \\
\hline & $f$ & Sig & $\mathrm{T}$ & Df & $\begin{array}{l}\text { Sig. (2- } \\
\text { tailed) }\end{array}$ & $\begin{array}{c}\text { Mean } \\
\text { differen } \\
\text { ce }\end{array}$ & $\begin{array}{c}\text { Std. error } \\
\text { differenc } \\
\text { e }\end{array}$ & Lower & $\begin{array}{l}\text { Upp } \\
\text { er }\end{array}$ \\
\hline $\begin{array}{l}\text { Equal } \\
\text { Variances } \\
\text { assumed }\end{array}$ & $\begin{array}{r}.02 \\
7\end{array}$ & .870 & $\begin{array}{r}.31 \\
9\end{array}$ & 58 & .751 & 1.000 & 3.132 & 5.269 & $\begin{array}{r}7.26 \\
9\end{array}$ \\
\hline $\begin{array}{l}\text { Equal } \\
\text { Variances not } \\
\text { Assumed }\end{array}$ & & & $\begin{array}{r}31 \\
9\end{array}$ & 57.980 & .751 & 1.000 & 3.132 & 5.269 & $\begin{array}{r}7.26 \\
9\end{array}$ \\
\hline
\end{tabular}

Berdasarkan tabel di atas, diperoleh signifikansi skor keterampilan proses sains siswa kedua kelompok berasal dari populasi yang berdistribusi normal adalah 0,751 . Nilai signifikansi ini lebih besar dari ketentuan taraf signifikansi $5 \%(\alpha$ $=0,05)$, sehingga berdasarkan kriteria pengambilan keputusan di atas, $\mathrm{H}_{0}$

diterima. Sehingga,

dapat disimpulkan bahwa rata-rata populasi kelompok pada pretest adalah sama. Artinya tidak terdapat perbedaan keterampilan proses sains siswa pada kelas eksperimen yang menggunakan metode storytelling dengan kelas kontrol yang menggunakan metode ceramah.

Tabel 2

Hasil Uji Perbedaan Dua Rerata Postest Kelas Eksperimen dan Kelas Kontrol

\begin{tabular}{|c|c|c|c|c|c|c|c|c|c|}
\hline \multicolumn{10}{|c|}{ t-tes for Equality of Means } \\
\hline \multirow{2}{*}{$\begin{array}{l}\text { Independent } \\
\text { Sample Test }\end{array}$} & \multicolumn{2}{|c|}{$\begin{array}{l}\text { Levene's } \\
\text { Test for } \\
\text { Equality } \\
\text { of } \\
\text { Variances }\end{array}$} & \multicolumn{5}{|c|}{ 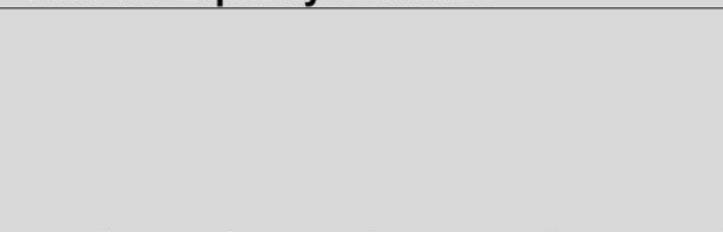 } & \multicolumn{2}{|c|}{$\begin{array}{c}95 \% \\
\text { Confidences } \\
\text { Interval of } \\
\text { the } \\
\text { Difference }\end{array}$} \\
\hline & $f$ & Sig & $\mathrm{t}$ & Df & $\begin{array}{l}\text { Sig. } \\
(2- \\
\text { tailed } \\
\quad)\end{array}$ & $\begin{array}{c}\text { Mean } \\
\text { differen } \\
\text { ce }\end{array}$ & $\begin{array}{c}\text { Std. } \\
\text { error } \\
\text { differen } \\
\text { ce }\end{array}$ & $\begin{array}{c}\text { Lowe } \\
r\end{array}$ & $\begin{array}{l}\text { Uppe } \\
\text { r }\end{array}$ \\
\hline $\begin{array}{l}\text { Equal } \\
\text { Variances } \\
\text { assumed }\end{array}$ & $\begin{array}{r}1.48 \\
1\end{array}$ & $\begin{array}{r}.22 \\
8\end{array}$ & $\begin{array}{r}4.74 \\
4\end{array}$ & 58 & .000 & 16.000 & 3.372 & 9.249 & $\begin{array}{r}22.75 \\
1\end{array}$ \\
\hline $\begin{array}{l}\text { Equal } \\
\text { Variances not } \\
\text { Assumed }\end{array}$ & & & $\begin{array}{r}4.74 \\
4\end{array}$ & $\begin{array}{r}55.7 \\
67\end{array}$ & .000 & 16.000 & 3.372 & 9.244 & $\begin{array}{r}22.75 \\
6\end{array}$ \\
\hline
\end{tabular}


Didaktik : Jurnal IImiah PGSD STKIP Subang, ISSN Cetak : 2477-5673 ISSN Online : 2614-722X Volume VI Nomor 01, Juni 2020

Tabel 2 menunjukkan bahwa nilai sig.(2-tailed) $<0,05(0,00<0,05)$, berdasarkan kriteria pengambilan keputusan di atas, maka $\mathrm{H}_{0}$ tidak diterima. Artinya rata-rata populasi kelompok pada postest adalah berbeda. Dengan demikian, dapat disimpulkan bahwa terdapat perbedaan rerata keterampilan proses sains antara kelompok siswa eksperimen yang menggunakan metode storytelling dengan kelompok kontrol yang menggunakan metode ceramah.

Gain digunakan untuk mengetahui perbedaan peningkatan kemampuan keterampilan proses sains siswa pada kedua kelompok, yaitu dengan membandingkan skor pretes dan postes. Hasil perhitungan gain ternormalisasi dapat dilihat pada lampiran. Dari data yang telah didapat mengenai gain ternormalisasi pada kelas eksperimen sebesar 0,47 yang termasuk ke dalam interpretasi sedang dengan kisaran $0,3<x \leq 0,7$ yaitu $0,3<0,47 \leq 0,7$. Sedangkan untuk kelas kontrol, data yang didapat menunjukkan hasil sebesar 0,14 dengan ketentuan $x \leq 0,3$ yang termasuk ke dalam interpretasi rendah. Dengan demikian, hasil yang diperoleh yaitu $0,14 \leq 0,3$ termasuk ke dalam

interpretasi

rendah. Berdasarkan perhitungan yang telah dilakukan dapat disimpulkan bahwa kemampuan keteramoilan proses sains siswa pada kelas eksperimen lebih tinggi dibandingkan dengan kelas kontrol yang pembelajarannya menggunanakan metode ceramah. Dengan interpretasi sedang untuk kelas eksperimen dan rendah untuk kelas kontrol.

\section{Hasil Penelitian dan Pembahasan}

Penelitian ini dilatarbelakangi dari adanya suatu permasalahan di lapangan mengenai keterampilan proses pada mata pelajaran IPA. Hasil Observasi yang telah dilakukan sebelumnya, terdapat dua pusat permasalahan yang timbul yaitu pada guru dan siswa. Permasalahan bermula ketika dalam pembelajaran, guru tidak menggunakan obyek yang nyata sebagai media pembelajaran. Di samping itu, guru hanya menjelaskan kepada siswa dengan sedikit atau tidak sama sekali memberikan kesempatan kepada siswa untuk ikut dalam proses pembelajaran. Hal inilah yang mengakibatkan keterampilan proses pada pembelajaran IPA tidak tampak sama sekali. Selain itu, menurut beberapa tanggapan siswa 
Didaktik : Jurnal IImiah PGSD STKIP Subang, ISSN Cetak : 2477-5673 ISSN Online : 2614-722X Volume VI Nomor 01, Juni 2020

bahwa IPA merupakan pembelajaran yang membosankan dan sulit untuk memahami materi-materi pada mata pelajaran IPA.

Selain itu, permasalahan yang berpusat pada siswa yaitu ketika pembelajaran berlangsung beberapa siswa banyak yang bergurau dan tidak menyimak dengan baik pembelajaran tersebut, ada pula yang mengantuk karena menurut beberapa siswa pembelajaran IPA kurang menantang untuk dipelajari. Hal ini karena keterampilan proses sains sama sekali tidak dikaitkan. Keterampilan proses sains tidak dapat dipisahkan dalam mata pelajaran IPA karena berkaitan dengan aktivitas siswa salah satunya yaitu mengobservasi.

Berangkat dari permasalahan tersebut, peneliti mencoba untuk memberikan proses pembelajaran yang berbeda dari sebelumnya yaitu dengan menggunakan metode storytelling. Metode Storytelling merupakan salah satu metode pembelajaran yang dapat menciptakan suasana pembelajaran yang aktif dan menyenangkan. Selain itu, dengan adanya suatu materi yang dibuat ke dalam suatu cerita, siswa dapat menyimak dengan baik. Hal ini karena siswa seakan-akan siswa merasa sedang mendengarkan cerita yang disampaikan guru, sehingga siswa merasa penasaran dan ingin mengikuti pembelajaran sampai pada kegiatan akhir. Dengan menggunakan metode storytelling, siswa dituntut untuk menjadi siswa yang aktif dan mampu untuk menggali pengetahuan dari obyek yang nyata dari sumbersumber yang relevan dan menemukan sendiri konsep baru.

Berkaitan dengan rumusan masalah yang telah disampaikan pada bab sebelumnya yang berkaitan dengan tiga keterampilan proses sains yaitu mengobservasi, mengomunikasi, dan menyimpulkan. Kemampuan keterampilan proses sains siswa sebelum dilaksananakan treatment baik pada kelas eksperimen dan kelas kontrol yang dilihat pada rata-rata hasil nilai pretest sebesar 50,67 untuk kelas eksperimen dan 49,67 untuk kelas kontrol. Rata-rata nilai pretest ini diasumsikan rendah karena jauh dari standar ketuntasan minimal yang telah ditentukan yaitu 69 .

Dalam penelitian ini, peneliti menggunakan dua sampel yaitu sebagai kelompok eksperimen dan kelompk kontrol yang diberikan perlakuan berbeda. Kelompok eksperimen dalam pembelajarannya 
Didaktik : Jurnal IImiah PGSD STKIP Subang, ISSN Cetak : 2477-5673 ISSN Online : 2614-722X Volume VI Nomor 01, Juni 2020

menggunakan metode storytelling dan kelompok kontrol menggunakan metode ceramah. Metode storytelling di kelas eksperimen bertujuan untuk mengaktifkan siswa dalam mengikuti pembelajaran dengan menyuguhkan obyek-obyek yang nyata disekitarnya. Hal ini sesuai dengan teori yang dikemukakan oleh Jean Piaget yang menyatakan bahwa anak usia 7-12 berada pada tahap operasional konkret. Artinya, siswa pada tahap operasional konkret ini, akan lebih baik apabila dalam proses pembelajarannya dihadapkan pada benda-benda konkret, sehingga siswa mampu untuk memahami dan mengonstruk pengetahuan yang didapat melalui benda-benda konkret tersebut.

Di samping itu, teori belajar lain yang mendukung digunakannya metode storytelling untuk membuat siswa aktif dalam pembelajaran dengan kegiatan-kegiatan yang dilakukan siswa dalam proses pembelajaran berkaitan dengan keterampilan proses sains adalah teori belajar yang dikemukakan oleh John Dewey dengan istilah Learning $B y$ Doing, yang mempunyai arti bahwa pembelajaran akan lebih dimaknai, dipahami, dan diingat selalu apabila belajar sambil melakukan, artinya siswa melakukan aktivitas-aktivitas terarah sesuai dengan pendekatan dan metode yang digunakan misalnya yaitu diskusi dan melakukan pengamatan. Dari hal tersebut siswa mampu untuk dapat mengobservasi, mengomunikasikan, dan menyimpulkan.

Teori lain yang mendukung adanya suatu pembelajaran yang membuat siswa merasa tertantang dan ingin mengikuti pembelajaran sampai pada kegiatan akhir, sehingga pembelajaran tersebut akan lebih bermakna bagi siswa yaitu teor yang dikemukakan oleh David Ausubel, yang menyatakan bahwa dengan adanya suatu pembelajaran yang membuat pembelajaran lebih bermakna siswa akan lebih tertantang siswa akan mengikuti langkah-langkah pada proses pembelajaran. Bermakna disini dimaksud bahwa pembelajaran tidak hanya berpusat kepada guru, melainkan ada tindakan-tindakan tertentu yang mengarahkan siswa pada suatu pembelajaran yang aktif dan menyenangkan. Salah satu tindakannya pada pembelajaran IPA dengan menerapkan keterampilan proses sains. 
Didaktik : Jurnal IImiah PGSD STKIP Subang, ISSN Cetak : 2477-5673 ISSN Online : 2614-722X Volume VI Nomor 01, Juni 2020

Sekaitan dengan teori-teori yang dikemukan di atas, hasil postest yang diperoleh kelompok kelas eksperimen menunjukkan angka 95 untuk nilai tertinggi dan 55 untuk nilai terendah dengan rata-rata sebesar 73,60. Sedangkan pada kelas kontrol hasil yang diperoleh untuk nilai tertinggi sebesar 80 dan 33 untuk nilai terendah dengan rata-rata nilai sebesar 57,50. Apabila dilihat dari rata-rata yang diperoleh dari pretest dan postest, baik kelompok eksperimen ataupun kelompok kontrol terdapat peningkatan kemampuan keterampilan proses setelah dilakukan treatment/perlakuan. Akan tetapi, untuk rata-rata nilai yang diperoleh yang menunjukkan peningkatan secara signifakn yaitu kelompok eksperimen yang pembelajarannya menggunakan metode storytelling.

Pengujian pada dua sampel ini dilanjutkan dengan melakukan uji-t. Pengujian statistik digunakan dengan menggunakan uji statistik parametrik, hal ini dikarenakan sayarat-syarat yang diajukan telah terpenuhi yaitu untuk menguji dengan uji statistik data harus berasal dari populasi yang berdistribusi normal dan tidak terdapat perbedaan varians antara kedua sampel yang berarti homogen.
Selanjutnya, data pretest dan postest diuji dengan menggunakan teknik Kolmogorov-Smirnov dengan bantuan SPSS Statistic 17.0 for Windows. Hasil yang diperoleh pada kelas eksperimen untuk nilai pretes menunjukkan nilai signifikansi sebesar 0,133 dan nilai signifikansi untuk postest yaitu sebesar 0,200. Karena kedua nilai signifikansi (sig. > 0,05) yaitu untuk pretest $0,133>0,05$ dan untuk postest 0,200 >0,05 maka $\mathrm{H}_{0}$ diterima. Artinya data pretest maupun postest berasal dari populasi yang berdistribusi normal. Disamping itu, untuk data kelompok kontrol menunjukkan nilai signifikansi untuk pretest sebesar 0,200 dan untuk postest sebesar 0,184. Kedua nilai signifakansi tersebut berasal dari data yang berdistribusi normal, karena nilai sig. > 0,05 yaitu 0,200>0,05 untuk pretest dan $0,184>0,05$ untuk postest.

Selanjutnya data di uji homogenitasnya. Adapun uji homogenitas dilakukan dengan uji $F$ yang dibantu dengan program SPSS Statistic 17.0 for Windows sehingga didapatkan hasil uji homogenitas untuk pretest pada kedua sampel nilai signifikansi sebesar 0,883 dan untuk postest sebesar 0,231. Karena nilai 
Didaktik : Jurnal IImiah PGSD STKIP Subang, ISSN Cetak : 2477-5673 ISSN Online : 2614-722X Volume VI Nomor 01, Juni 2020

sig. $>0,05$ yaitu $0,883>0,05$ untuk pretest dan $0,231>0,05$ untuk postest, maka $\mathrm{H}_{0}$ diterima. Dengan demikian, dapat disimpulkan bahwa kedua data baik pretest maupun postest pada kedua sampel tidak memiliki perbedaan variansi yang diartikan bahwa data tersebut homogen.

Pengolahan data berikutnya yaitu dengan melakukan uji-t, dari hasil pengujian didapat nilai signifikansi 2-tailed untuk pretest pada kedua sampel sebesar 0,751 . Hal ini berarti nilai sig.2-tailed $>0,05$, maka $\mathrm{H}_{0}$ diterima. Artinya bahwa tidak terdapat perbedaan rerata kemampuan keterampilan proses sains antara kedua kelompok sampel. Berbeda halnya setelah kedua kelompok sampel diberikan perlakuan yang berbeda dan kemudian diberikan postest. Hasil yang didapatkan dari data postest menunjukkan nilai sig.2tailed $<0,05$ sehingga $\mathrm{H}_{0}$ ditolak dengan asumsi bahwa terdapat perbedaan rerata kemampuan keterampilan proses sains antara kedua kelompok sampel setelah diberi perlakuan yang berbeda

Hasil pengujian yang telah diuraikan di atas menunjukkan jawaban dari hipotesis dan rumusan masalah pertama yang menyatakan bahwa terdapat perbedaan yang signifikan kemampuan keterampilan proses sains yang belajar menggunakan metode storytelling dibandingkan dengan belajar menggunakan metode ceramah. Pernyataan tersebut sejalan dengan penelitian yang dilakukan oleh Ade Helyan (2010) yang berjudul "Penggunaan Metode Bercerita Untuk Meningkatkan Hasil Belajar Siswa Pada Konsep Kenampakan Permukaan Bumi". Diperoleh kesimpulan bahwa metode bercerita (storytelling) berpengaruh terhadap hasil belajar siswa. Hasil belajar siswa yang diperoleh pada setiap siklusnya yaitu pada siklus I diperoleh rata-rata 70,2 , pada siklus II rata-rata 73,8 , dan pada siklus III rata-rata nilai 83,5 . Selain itu, pada salah satu jurnal yang ditulis oleh Yanthi, Novi (2009) yang berjudul "Pembelajaran IPA secara Dwibahasa melalui metode bercerita untuk meningkatkan Multiple Intelligences Siswa SD Laboratorium UPI Kampus Cibiru". Hasil yang diperoleh menyatakan bahwa metode bercerita dapat meningkatkan Multiple Inteligences siswa yaitu kecerdasan naturalis, linguistik, visual-spasial, dan interpersonal siswa. 
Didaktik : Jurnal IImiah PGSD STKIP Subang, ISSN Cetak : 2477-5673 ISSN Online : 2614-722X Volume VI Nomor 01, Juni 2020

Penelitian lainnya yaitu dengan menguji hasil skala rating untuk mengetahui keterampilan proses sains siswa dengan menggunakan metode storytelling. Hasil pengujian yang diperoleh menunjukkan skor keseluruhan 310 dari skor 360 yang diharapkan dengan prosentase 86,1\% dengan kategori cukup baik atau dapat dikatakan pula baik. Dengan rata-rata jumlah skor dari setiap keterampilan proses yang diharapkan yaitu 104 untuk keterampilan observasi, 103 untuk mengomunikasikan, dan 103 untuk menyimpulkan. Hasil pengujian tersebut menjawab rumusan masalah yang kedua bahwa keterampilan proses sains yang diperoleh siswa pada kelas eksperimen yang menggunakan metode storytelling termasuk ke dalam kategori cukup baik atau baik.

\section{Kesimpulan}

Berdasarkan analisis data dan hasil penelitian yang telah dilakukan, maka dapat ditarik beberapa kesimpulan dari rumusan masalah yang telah diajukan, untuk rumusan yang pertama bahwa kelompok eksperimen yang pembelajarannya menggunakan metode storytelling menunjukkan data dalam kemampuan keterampilan proses sains lebih tinggi dibandingkan dengan kelompok kontrol. Hal tersebut dapat dilihat dari nilai rata-rata hasil postest sebesar 73,60 sedangkan pada kelas kontrol sebesar 57,50. Hal ini mengasumsikan bahwa metode storytelling sebagai salah satu metode pembelajaran yang memberikan kontribusi positif dalam kemampuan keterampilan proses sains yang dimiliki siswa sehingga dapat dikatakan metode storytelling sebagai salah satu bentuk pembaharuan metode dalam pembelajaran.

Berkaitan dengan rumusan masalah yang kedua yaitu mengenai bagaimana kemampuan keterampilan proses sains siswa pada kelompok eksperimen setelah diberikan perlakuan menunjukkan prosentase sebesar 86,1\% Artinya prosentase tersebut termasuk ke dalam kategori cukup baik atau dapat dikatakan baik, hasil perhitungan ini sesuai dengan hasil perhitungan gain ternormalisasi yang didapat dari soal tes dengan interpretasi sedang.

Dari ketiga keterampilan proses sains yang diajukan, keterampilan yang menunjukkan skor tertinggi yaitu keterampilan mengobservasi. Hal ini 
Didaktik : Jurnal IImiah PGSD STKIP Subang, ISSN Cetak : 2477-5673 ISSN Online : 2614-722X Volume VI Nomor 01, Juni 2020

disebabkan karena adanya rasa ingin tahu yang dimiliki siswa tentang materi yang disampaikan guru. Disamping itu pula, siswa sangat antusias dalam melakukan observasi karena pada pembelajaran-pembelajaran

sebelumnya langkah ini dapat dikatakan jarang atau tidak dilakukan sama sekali oleh guru yang bersngkutan. Untuk itu, siswa pada kelas eksoerimen merasa senang dengan adanya kegiatan pembelajaran yang menantang. Berdasarkan uraian yang telah dikemukakan, dapat disimpulkan bahwa metode storytelling berpengaruh terhadap kemampuan keterampilan proses sains siswa yaitu mengobservasi, mengomunikasikan, dan menyimpulkan.

\section{DAFTAR PUSTAKA}

Abidin, Y. (2011). Penelitian Pendidikan Dalam Gamintan Pendidikan Dasar Dan PAUD.Bandung : Rizqi

Ade Helyan. (2010).Penggunaan Metode Bercerita Untuk Meningkatkan Hasil Belajar Siswa Pada Konsep Kenampakan Permukaan Bumi. Skipsi Jurusan Pendidikan Guru Sekolah Dasar UPI. Bandung: tidak ditebitkan.

Arikunto, S. (2006). Prosedur Penelitian Suatu Pendekatan. Jakarta: Rineka Cipta.
Bundu, P. (2006). Penilaian Keterampilan Proses Dan Sikap IImiah Dalam Pembelajaran Sains - SD. Jakarta: Departemen Pendidikan Nasional.

Dahar, R.W. (1996). Teori - Teori Belajar. Bandung: Erlangga.

Departemen Pendidikan Nasional. (2006). Kurikulum 2006. Jakarta: Media Makmur Maju Mandiri.

Esler. (1996). Teaching Elemnetary Science.Washington: Wadsworth Publishing Company.

Hendrayana, Sopyan. (2010). Meningkatkan Keterampilan Berpikir Rasional Siswa Melalui Model Sains Teknologi Masyarakat Pada Konsep Sumber Daya Alam (Suatu PTK terhadap siswa kelas IV Dasar Negeri CikalangKecamatan Cileunyi Kabupaten Bandung). Skipsi Jurusan Pendidikan Guru Sekolah Dasar UPI. Bandung: tidak diterbitkan.

Mulyati, T., Yuniarti, Y., dan Abidin, Y. (2011). Statistika Terapan Untuk Penelitian Pendidikan Dasar dan PAUD. Bandung: Rizqi.

Muslim, dkk. (2009). IImu Pengetahuan Alam dan Lingkungaku. Bandung: PT Setia Purna Inves

Sagala, S. (2008). Konsep dan Makna Pembelajaran. Bandung: Alfabeta.

Scoot. And Ytrebrg.(2009). Inggris Teaching English to Children. New York: Oxford Univerversity Press.

Sugiyono. (2010). Metode Penelitian Kuantitatif Kualitatif dan $R \& D$. Bandung: Alfabeta.

Sulaeman, D. (2010). Penggunaan Pendekatan Keterampilan Proses Untuk Meningkatkan Hasil Belajar Siswa Pada Pembelajaran Energi 
dan Penggunaannya. Skripsi Sarjana pada FIP UPI Bandung: tidak diterbitkan.

Yanthi, N. (2009). "Pembelajaran IPA Secara Dwi Bahasa Melalui Metode Bercerita Untuk Meningkatkan Multiple Intelligences Siswa SD Laboratorium UPI Kampus Cibiru". Jurnal Eduhumaniora. 1, (1), 65-73.

Yulianti, S. (2009).Meningkatkan Keterampilan Proses Sains Pada Konsep Energi Panas Di Kelas IV SD MelaluiModel Interaktif.Skipsi Jurusan Pendidikan Guru Sekolah Dasar UPI. Bandung: tidak ditebitkan.

Yuliariatiningsih, M.S. Dan Irianto, D.M. Pendidikan IPA Di Sekolah Dasar.Bandung: UPI Press. 